Note

\section{Bioassay of Ansamitocin P-3, an Antitumor Antibiotic}

\author{
Kazunori Hatano, Eiji Higashide \\ and Masahiko YonedA
}

Applied Microbiology Laboratories, Central Research Division,

Takeda Chemical Industries, Ltd., 17-85, Juso-honmachi 2-chome, Yodogawa-ku, Osaka 532, Japan

Received November 4, 1983

Ansamitocins, ${ }^{1)}$ produced by Actinosynnema pretiosum subsp. pretiosum No. C-15003 (Synonym: Nocardia sp. No. C-15003), ${ }^{2,3)}$ have antileukemic activity, ${ }^{4)}$ and inhibit the growth of eukaryotic microorganisms, but not that of prokaryotes. ${ }^{2)}$ In ansamitocin fermentation, A. pretiosum subsp. pretiosum No. C-15003 mainly produces ansamitocin P-2, P-3 and P-4 in the ratio of about $15: 55: 30{ }^{5)}$ but, in the presence of valine, selectively produces ansamitocin P-3. ${ }^{6)}$ To establish a process for the fermentative production of ansamitocin $\mathrm{P}-3$, it is necessary to determine the antibiotic in a large number of fermentation samples. In an early study on the production of ansamitocin P-3, we tried to assay ansamitocin P-3 by the method of Hanka and Barnett ${ }^{7)}$ using Penicillium avellaneum. This assay method, however, could not be applied to our present study because the susceptibility to ansamitocin P-3 was low and the edge of the zone of inhibition was obscure. Therefore, we established a more favorable method for the assay of ansamitocin P-3.

To select the test organism, 396 strains of yeast from the Institute for Fermentation, Osaka (IFO), were employed. Among them, Filobasidium uniguttulatum IFO 0699 was selected as the most suitable test organism, based on the highest susceptibility to ansamitocin P-3 and the formation of a clear edge of the inhibition zone. The test organism was inoculated on a slant medium (Trypticase soy agar (BBL), supplemented with $1 \%$ glucose) and incubated at $28^{\circ} \mathrm{C}$ for $66 \mathrm{hr}$. A loopful of the culture was inoculated into $5 \mathrm{ml}$ of Trypticase soy broth (BBL) in a test tube and the inoculant was incubated at $28^{\circ} \mathrm{C}$ for $18 \mathrm{hr}$ on a reciprocal shaker. The resultant culture (about $5 \times 10^{8}$ cells $/ \mathrm{ml}$ ) was diluted 10 -fold with $0.9 \% \mathrm{NaCl}$ solution and $0.5 \mathrm{ml}$ of the diluent was seeded into $100 \mathrm{ml}$ of an assay medium (Trypticase soy agar supplemented with $1 \%$ glucose and $0.5 \% \mathrm{NaCl})$ at about $42^{\circ} \mathrm{C}$. The seeded medium $(10 \mathrm{ml})$ was poured into plastic Petri-dishes $(9-\mathrm{cm}$ diameter) to make plates. The assay was carried out by the agar-well method: Four wells were cut in each seeded agar plate with a cylinder punch (8-mm diameter) and then filled with $50-\mu$ l sample solutions. Plates were incubated at $28^{\circ} \mathrm{C}$ for $42 \mathrm{hr}$. Each component, ansamitocin P-2, P-3 and P-4, was dissolved in methanol and the solutions were serially diluted with $0.1 \mathrm{M}$ phosphate buffer $(\mathrm{pH}$ 7.0) to final concentrations of $20,10,5,2.5,1.25$ and $0.63 \mu \mathrm{g} / \mathrm{ml}$, before use. Dose-response curves of P-2, P-3 and P-4 were constructed by plotting the average zone diameter $(\mathrm{mm})$ against the concentration $(\mu \mathrm{g} / \mathrm{ml})$ on semi-logarithmic section paper (Fig. 1). The relative susceptibilities of ansamitocin P-2 and P-4 to that of P-3 were 44 and $152 \%$, respectively. Concentrations of ansamitocin P-3 in unknown samples were calculated from the curve of P-3.

In order to evaluate the accuracy of the assay method, error and reproducibility of the assay results were exam-

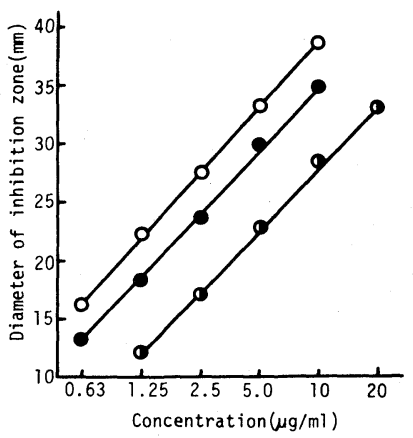

FIG. 1. Dose-response Curves of Ansamitocin P-2, P-3 and P-4.

The regression lines of P-2 ( $),$ P-3 (O) and P-4 (O) are $Y=18.1 \log X+10.1, \quad Y=18.1 \log X+16.9$ and $Y=18.3$ $\log X+20.2$, respectively. $Y$, diameter of inhibition zone $(\mathrm{mm}) ; X$, concentration of each ansamitocin component $(\mu \mathrm{g} / \mathrm{ml})$.

TABle I. INFLUENCE OF ANSAMItocin P-2 AND P-4 ON DETERMINATION of Ansamitocin P-3

The test was carried out by the agar-well method using Filobasidium uniguttulatum IFO 0699. The plates were incubated at $28^{\circ} \mathrm{C}$ for $42 \mathrm{hr}$.

\begin{tabular}{clll} 
Concentration of ansamitocin $(\mu \mathrm{g} / \mathrm{ml})$ & $\begin{array}{c}\text { Detection } \\
\text { as P-3 } \\
(\mu \mathrm{g} / \mathrm{ml})\end{array}$ \\
\cline { 1 - 3 } $\mathrm{P}-3$ & $\mathrm{P}-2$ & $\mathrm{P}-4$ & 5.0 \\
5 & - & - & 5.0 \\
5 & 0.5 & - & 5.1 \\
5 & 1.0 & - & 5.4 \\
5 & 1.5 & - & 5.9 \\
5 & 2.0 & - & 5.1 \\
5 & - & 0.5 & 5.4 \\
5 & - & 0.75 & 6.0 \\
5 & - & 1.0 & 5.1 \\
5 & 0.25 & 0.25 & 5.4 \\
5 & 0.5 & 0.5 & 5.6 \\
5 & 0.75 & 0.75 & \\
\hline
\end{tabular}


TABLE II. Reproducibility Test

\begin{tabular}{|c|c|c|c|c|c|c|c|}
\hline Sample & & & $\begin{array}{c}\text { Detection } \\
(\mu \mathrm{g} / \mathrm{ml})\end{array}$ & & & $\begin{array}{c}\text { Average } \\
(\mu \mathrm{g} / \mathrm{ml})\end{array}$ & $\begin{array}{l}\text { Standard } \\
\text { deviation }\end{array}$ \\
\hline 1 & 4.8 & 4.4 & 4.7 & 4.6 & 4.8 & 4.7 & 0.17 \\
\hline 2 & 6.2 & 6.4 & 6.2 & 6.4 & 6.9 & 6.4 & 0.29 \\
\hline 3 & 10.5 & 9.2 & 9.9 & 9.6 & 9.3 & 9.7 & 0.52 \\
\hline 4 & 12.0 & 13.2 & 12.8 & 13.0 & 13.0 & 12.8 & 0.47 \\
\hline 5 & 20.0 & 19.0 & 19.8 & 19.3 & 19.2 & 19.5 & 0.42 \\
\hline
\end{tabular}

ined. Table I shows that the error of the assay of P-3 was less than $10 \%$ even if the sample contained $30 \% \mathrm{P}-2,15 \%$ $\mathrm{P}-4$ or $10 \%$ of each them in relation to the concentration of P-3. Table II shows the high reproducibility of the test results, based on the standard deviation. In addition, the recovery yield of a known amount of ansamitocin P-3 added to the fermentation broth was in the range of 95.8 to $105 \%$ (data not shown).

These results indicate that the bioassay method described above is useful for determining ansamitocin P-3 in broth samples.

Acknowledgments. The authors are grateful to Dr. E. Ohmura for his encouragement, and to Mrs. K. Jinno and Mr. S. Iinuma for their skillful technical assistance.

\section{REFERENCES}

1) E. Higashide, M. Asai, K. Ootsu, S. Tanida, Y.
Kozai, T. Hasegawa, T. Kishi, Y. Sugino and M. Yoneda, Nature, 270, 721 (1977).

2) S. Tanida, T. Hasegawa, K. Hatano, E. Higashide and M. Yoneda, J. Antibiot., 33, 192 (1980).

3) T. Hasegawa, S. Tanida, K. Hatano, E. Higashide and M. Yoneda, Int. J. Syst. Bacteriol., 33, 314 (1983).

4) K. Ootsu, Y. Kozai, M. Takeuchi, S. Ikeyama, K. Igarashi, K. Tsukamoto, Y. Sugino, T. Tashiro, S. Tsukagoshi and Y. Sakurai, Cancer Res., 40, 1707 (1980).

5) M. Izawa, K. Haibara and M. Asai, Chem. Pharm. Bull., 28, 789 (1980).

6) K. Hatano, E. Higashide, S. Akiyama and M. Yoneda, Agric. Biol. Chem., 48, 1721 (1984).

7) L. J. Hanka and M. S. Barnett, Antimicrob. Agents and Chemother., 6, 651 (1974). 